\title{
Predicting Morbidity and Mortality in Patients with Lower Extremity Necrotizing Fasciitis
}

\author{
(D) Fatih Irmak, () Semra Karşıdağ \\ Department of Plastic, Reconstructive and Aesthetic Surgery, Health Sciences University, Şişli Hamidiye Etfal Application and Research \\ Center, İstanbul, Turkey
}

\begin{abstract}
Objectives: Necrotizing fasciitis (NF) is a rare but limb- and life-threatening soft-tissue infection. It is among the most challenging surgical infections faced by surgeons, and is often accompanied by severe systemic toxicity. The aim of this study was to evaluate the predictive power of serum lactate and creatinine levels for mortality and morbidity in lower extremity NF.

Methods: A retrospective cohort analysis of 87 patients with lower extremity NF was performed to evaluate the management techniques and the amputation and survival rates according to serum lactate and creatinine levels as well as the time between the onset of symptoms and surgery.

Results: The mean time between the onset of symptoms and surgery was 3.7 days. As the time between the onset of symptoms and surgery increased, the rate of amputation and mortality significantly increased $(p<0.001)$. In all, $66 \%$ of the mortality in the group was seen among the 12 patients who had a serum creatinine level greater than $2 \mathrm{mg} / \mathrm{dL}$ at the time of presentation. In 12 of 14 patients (85.7\%) who underwent amputation/disarticulation, the mean serum lactate level was $5.7 \mathrm{mmol} / \mathrm{L}$ (range: $5.1-8.7$ $\mathrm{mmol} / \mathrm{L}$ ), and the mean serum creatinine level was $1.92 \mathrm{mg} / \mathrm{dL}$ (range: 1.4 to.3.3 $\mathrm{mg} / \mathrm{dL}$ ). The high levels of serum creatinine and lactate were found to be statistically significant in terms of predicting mortality and amputation $(p<0.001)$.

Conclusion: Based on the results of this study, it was determined that risk factors for mortality include age, late presentation, increased serum creatinine and lactate levels, and that these factors can predict the rate of death from NF at the time of presentation. Keywords: Necrotizing fasciitis; serum creatinine; serum lactate.
\end{abstract}

Please cite this article as "Irmak F, Karşıdağ S. Predicting Morbidity and Mortality in Patients with Lower Extremity Necrotizing Fasciitis. Med Bull Sisli Etfal Hosp 2019;53(1):27-32".

$\mathrm{N}$ ecrotizing fasciitis (NF) is a progressive, life-threatening, inflammatory infection that primarily affects the fascia and can secondarily cause necrosis in subcutaneous tissues. NF was first described by Hippocrates in the fifth century B.C. as a complication of "erysipelas." During the US Civil War, a Confederate Army surgeon named Joseph Jones described this infection as "hospital gangrene," one which caused the death of $46 \%$ of 2642 afflicted soldiers. ${ }^{[1]}$ The annual incidence of NF in the US is between 500 and 1000, while the incidence around the world is around 0.40 in $100.000{ }^{[2]}$ Although there have been many advancements and improvements in the diagnosis and treatment of this disease, the mortality rate varies dramatically from $9.3 \%$ to $76 \%{ }^{[3]}$

There are many different classifications systems based on the requirement for surgical management, microbiological characteristics (bacterial synergistic gangrene, streptococcal gangrene, and clostridial or fungal infections), and involvement areas (skin and subcutaneous tissue, subcutaneous tissue and fascia, and muscle). ${ }^{[4-8]}$ However, none of these classifications is essential for the management of NF. All NF cases should promptly undergo surgical debride-

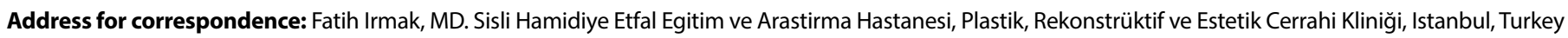
Phone: +90 5064743866 E-mail: dr.fatihirmak@gmail.com

Submitted Date: November 27, 2018 Accepted Date: January 28, 2019 Available Online Date: February 04,2019

${ }^{\circ}$ Copyright 2019 by The Medical Bulletin of Sisli Etfal Hospital - Available online at www.sislietfaltip.org

This is an open access article under the CC BY-NC-ND license (http://creativecommons.org/licenses/by-nc/4.0/). 
ment, broad-spectrum antibiotics should be administered, and nutritional support should be considered. NF can arise in almost any area of the body upon disruption of the skin from laceration due to local trauma, insect bite, needle puncture, burn, skin abscess, chronic venous ulcer, or increased temperature of an operated area after an invasive procedure. ${ }^{[9]}$ With progression of the disease, the spread of hyperemic lesions, vesicle formation, subcutaneous crepitation, and thickening of the subcutaneous tissue can occur. While early diagnosis can be lifesaving, referral of patients to treatment centers is often delayed due to misdiagnosis, particularly in developing countries. The fundamental treatment in NF is surgical debridement, which must be accompanied by antibiotic therapy.

There are readily available, complex tools for determining mortality in NF patients, such as novel scoring systems for the severity of illness and clinical prediction rules, but these scoring systems are not always practical for routine clinical use. On the other hand, lactate and creatinine kinase level measurements are usually readily available for clinical use. They are simple to use and implement. In previous studies serum lactate and creatinine kinase levels have been associated with increased mortality in sepsis and electrical burn patients. ${ }^{[10-12]}$ There are a few studies on the value of serum lactate and creatinine kinase levels for the diagnosis of $\mathrm{NF}^{\left[{ }^{[13-}\right.}$

${ }^{15]}$ These studies do not, however, evaluate the morbidity or mortality associated with the level of these enzymes.

This retrospective cohort study was focused on risk factors that were associated with amputation and mortality rate in lower extremity NF patients. The aim was to determine the presentation, management, treatment modalities, and outcome of lower extremity NF cases. Furthermore, the objective was to emphasize the importance of serum creatinine/lactate levels and early diagnosis in the improvement of patient prognosis and the suitability of elevated lactate and creatinine as a predictive morbidity and mortality parameter in NF.

\section{Methods}

A retrospective review of the medical records of patients who were admitted with lower extremity NF between January 2013 and June 2017 (54 months) was performed.

Informed consent was obtained from all of the participants. Ethical approval was not required due to the retrospective design of the study.

Potentially eligible patients were identified through a hand search of operating room (handwritten) logbooks using the search terms of "lower extremity necrotizing fasciitis," "thigh necrotizing fasciitis," "crus necrotizing fasciitis," "foot necrotizing fasciitis," and "ankle necrotizing fasciitis." Patients with Fournier's gangrene or NF involving the head, neck, upper extremities or the trunk were excluded.

The diagnosis of NF was confirmed during surgery by foulsmelling discharge (dishwater fluid), loss of integrity of the fascia, and necrosis or lack of bleeding of the muscle and fascia during dissection. An intra-operative biopsy with Gram stain was used in some cases, but was not necessary for the diagnosis, as findings from the exploratory surgery were often definitive. Biopsies and microbiological samples were collected from all of the patients.

The study population was 87 patients. All patients' age, gender, and history of trauma at the time of presentation were recorded, and the time between the onset of disease and presentation, the duration of hospital stay, the number of surgical operations performed, and the serum creatinine and lactate levels at the time of presentation were analyzed in terms of complications, mortality, and morbidity. Patient information was obtained via routine controls, medical records, and phone calls.

\section{Statistical Analysis}

The statistical analysis was performed using SPSS for Windows, Version 15.0 (SPSS Inc., Chicago, IL, USA). The Man$\mathrm{n}$-Whitney test to compare different groups (unpaired, non-parametric). A p value less than 0.05 was considered significant.

\section{Results}

A total of 87 patients, 33 females and 54 males, were included in the study. The mean age was 50.6 years (range: 22-74 years). At the time of presentation, 37 patients had uncontrolled diabetes, 17 had cellulitis, 6 had venous insufficiency, 4 had HIV infection, 5 had a previous history of autoimmune disease, 4 had a previous history of malignancy and distant metastasis at the time of presentation, and 14 patients did not have any precursor-comorbidity factors.

Pain, localized sensitivity, skin erythema, and increased temperature were the most common symptoms of the physical examination. Blisters and bulbous skin were present in 41 patients, 26 patients had skin necrosis, 5 patients had symptoms of peau d'orange edema of the skin. Three patients also had symptoms at the ipsilateral upper extremity, including 2 patients who had 4-extremity gangrene symptoms, which became apparent in the preoperative period in 1 patient, and which arose in the postoperative period with rapid progression in the other patient.

The mean time between the onset of symptoms and surgery was 3.7 days (range: 2-11 days). Among the 26 patients with more than 5.5 days between the onset of symptoms and surgery, 12 underwent amputation, 2 underwent disarticulation, and 8 died. In patients who had fewer than 
5.5 days between onset and surgery, appropriate reconstruction was performed without any need for amputation, and none of the patients died. As the time between the onset and surgery increased, the rate of amputation/disarticulation and mortality increased significantly $(p<0.001)$.

The mean serum lactate level at the time of presentation was $4.14 \pm 2.30 \mathrm{mmol} / \mathrm{L}$ (range: $1.2-12.7 \mathrm{mmol} / \mathrm{L}$; normal level: $0.5-2.2 \mathrm{mmol} / \mathrm{L}$ ). The mean serum creatinine level at the time of presentation was $1.76 \pm 0.39 \mathrm{mg} / \mathrm{dL}$ (range: 1.2-3.3 mg/dL; normal level 0.6-1.2 mg/dL). In patients who underwent amputation/disarticulation, the mean serum lactate level was $5.7 \mathrm{mmol} / \mathrm{L}$ (range: 5.1 to $8.7 \mathrm{mmol} / \mathrm{L}$ ), and the mean serum creatinine level was $1.92 \mathrm{mg} / \mathrm{dL}$ (range: 1.4 to.3.3 mg/dL). Therefore, the high levels of serum creatinine and lactate were found to be statistically significant in terms of mortality and amputation $(p<0.001)$ (Table 1$)$. A $66 \%$ mortality rate was determined among the 12 patients who had a serum creatinine level greater than $2 \mathrm{mg} / \mathrm{dL}$ at the time of presentation.

The serum lactate level measured after completion of the final debridement, prior to reconstruction was found to be close to normal; the mean value was $2.10 \pm 0.61 \mathrm{mmol} / \mathrm{L}$ (range: 0.7 $3.3 \mathrm{mmol} / \mathrm{L}$ ). The mean serum creatinine level measured after completion of the final debridement, prior to reconstruction was $0.9 \mathrm{mg} / \mathrm{dL}$ (range: $0.7-1.13 \mathrm{mg} / \mathrm{dL}$ ). The preoperative and postoperative serum lactate and creatinine values were compared, and it was determined that the postoperative values were significantly lower $(p<0.001)$ (Table 1).

The most common agents observed in the culture were Staphylococcus aureus $(n=53,61 \%)$, Acinetobacter baumannii $(n=10,11.5 \%)$, methicilline-resistant Staphylococcus aureus $(n=14,16 \%)$, Pseudomonas aeruginosa $(n=29$, $33.3 \%)$, and Escherichia coli $(n=41,47.1 \%)$. Fungal culture was not routinely performed. Four patients were found to be $\mathrm{HIV}+$ in routine tests.

Reconstruction in NF patients was performed within the mean value of 25.2 days (range: 9-47 days) after the first presentation, once the symptoms had regressed and complete cleanliness of the defective lesion was confirmed. Reconstructive surgery was considered only once the patient's general condition was stable and the infection was fully eradicated. Wound reconstruction was performed

Table 1. Average values of serum lactate and creatinine levels

\begin{tabular}{|c|c|c|c|c|}
\hline & $\begin{array}{l}\text { Initial value at the time } \\
\text { of presentation }\end{array}$ & $\begin{array}{l}\text { Value following the } \\
\text { completion of debridements }\end{array}$ & $\begin{array}{l}\text { Initial value in } 12 \text { patients } \\
\text { who required amputation }\end{array}$ & $\mathbf{p}$ \\
\hline Serum lactate (mmol/L) & $\begin{array}{c}4.14 \pm 2.30 \\
\text { (Range: } 1.2 \text { to } 12.7 \text { ) }\end{array}$ & $\begin{array}{c}2.10 \pm 0.61 \\
\text { (Range: } 0.7 \text { to } 3.3 \text { ) }\end{array}$ & $\begin{array}{c}5.7 \\
\text { (Range: } 5.1 \text { to } 8.7 \text { ) }\end{array}$ & $\mathrm{p}<0.001$ \\
\hline Serum creatinine (mg/dL) & $\begin{array}{c}1.76 \pm 0.39 \\
\text { (Range: } 1.2 \text { to } 3.3 \text { ) }\end{array}$ & $\begin{array}{c}0.90 \pm 0.18 \\
\text { (Range: } 0.7 \text { to } 1.3 \text { ) }\end{array}$ & $\begin{array}{c}1.92 \\
\text { (Range } 1.4 \text { to.3.3) }\end{array}$ & $\mathrm{p}<0.001$ \\
\hline
\end{tabular}

Table 2. Analysis and demographics of patients who underwent amputation

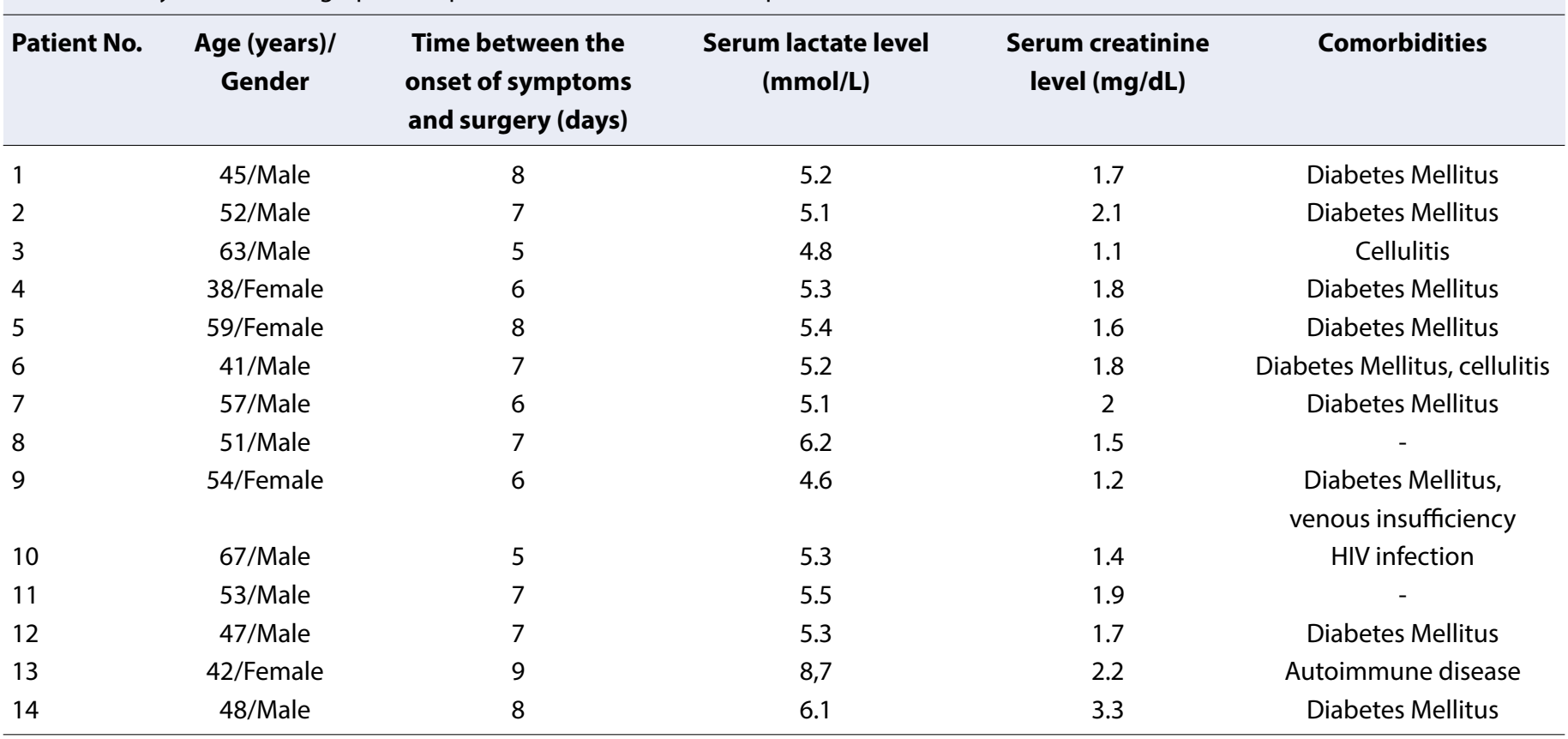




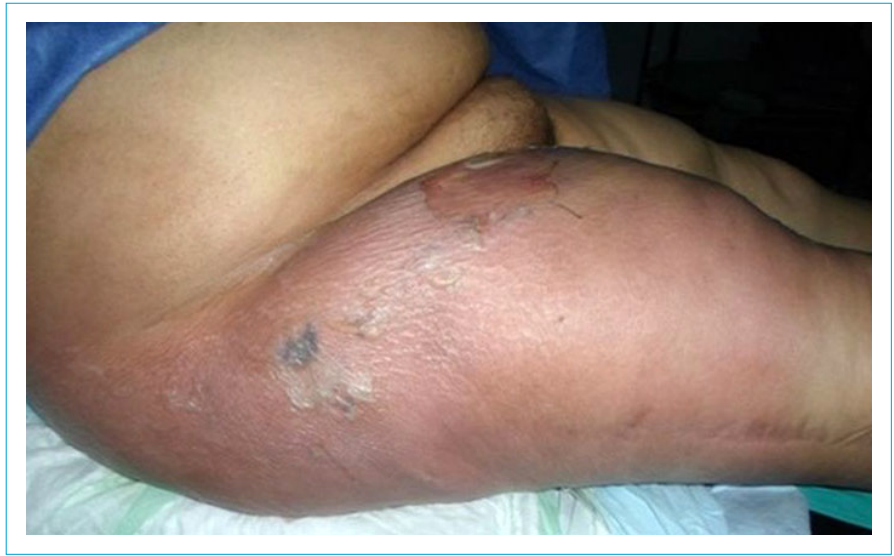

Figure 1. Preoperative appearance of necrotizing fasciitis in the right thigh.

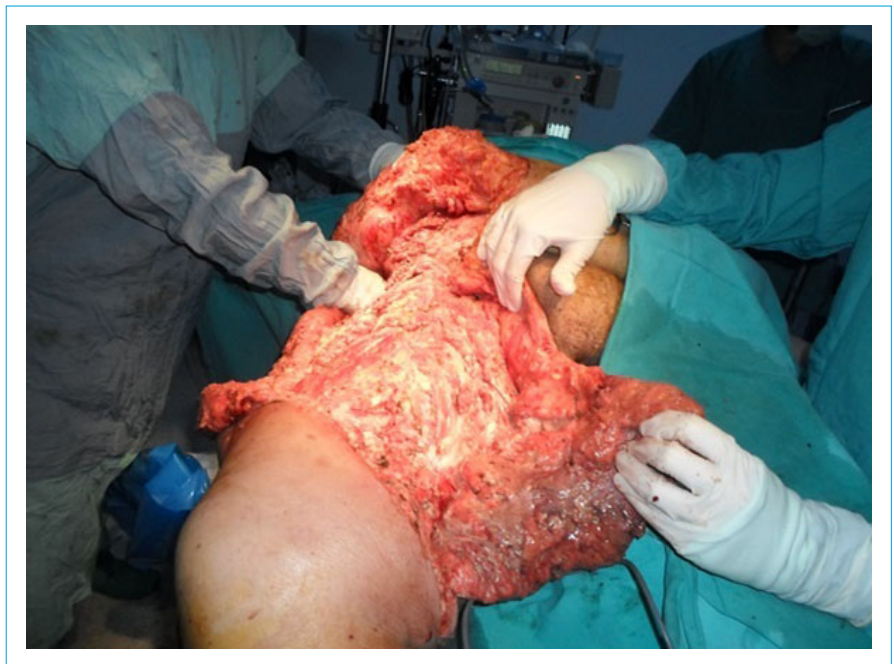

Figure 2. Necrotizing fasciitis has progressed to the pubic and abdominal levels after perioperative debridement.

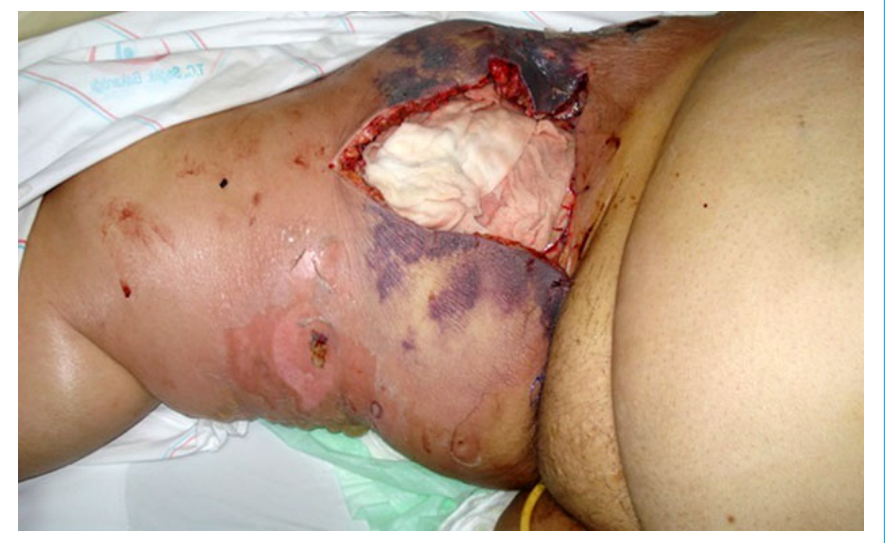

Figure 3. The appearance after sufficient time was allowed for the skin necrosis to settle before definitive reconstruction.

using skin grafting $(n=24,27.6 \%)$, local flap adaptation $(n=17,19.5 \%)$, single extremity amputation $(n=9,10.3 \%)$, and 2 extremity amputations $(n=3,3.4 \%)$. Amputation was performed in 12 patients (13.8\%) (Table 2 ) and secondary

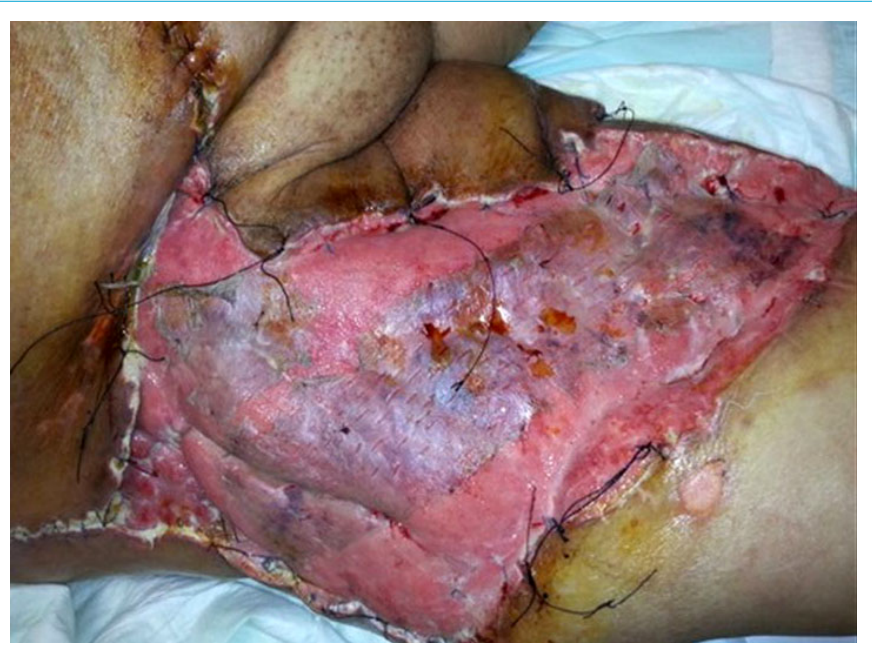

Figure 4. The appearance after reconstruction using a split-thickness skin graft.

intention or primary closure was performed in 35 patients (40.2\%).

In cases where multiple surgical debridements could not bring the infection under control, disarticulation of the lower extremity was performed $(n=2,2.3 \%)$. The overall mortality rate was $9.2 \%(n=8)$. The most common major complication of NF was septicemia $(n=56,64.4 \%)$. Other minor complications were nosocomial infections and endophthalmitis. All of the deaths were the result of septicemia and multiple organ failure.

The mean value of the number of surgical debridements required was 2.8 (range: 1-9). The site of NF was the ankle and foot in 41 patients (47.1\%), the crus in 28 patients (32.2\%), and the thigh in 18 patients (20.7\%). Intra-operatively, among the 18 patients who had NF of the thigh region, 7 were found to have extension of the disease to the groin and abdominal area (Fig. 1-4). Infection control failed after multiple debridements in 2 patients, and led to total limb loss-disarticulation.

Of the 87 patients, 25 had a massive tissue defect and once the infection was brought under control surgically and medically, negative pressure wound therapy (NPWT) treatment was initiated under $125 \mathrm{mmHg}$ pressure. The NPWT closure was changed every 48 to 72 hours. NPWT dramatically improved the state of the wound surface and the overall condition of the patients.

\section{Discussion}

$\mathrm{NF}$ is a disease that rapidly destroys the subcutaneous tissue and fascia and requires emergency debridement as soon as the diagnosis is made. Conditions such as diabetes, atherosclerosis, cancer, bone marrow dysplasia, chronic alcoholism, 
severe malnutrition, and peripheral vascular disease are predisposing factors for $\mathrm{NF}^{[5,16,17]}$ Although the occurrence of $\mathrm{NF}$ is usually based on predisposing risk factors, the infection can also occur in apparently healthy individuals.

One of the early distinguishing marks of NF is erysipelas. Other important symptoms are severe pain that is inconsistent with other symptoms and reduced tissue tension and tonus. In the early stages, NF can be confused with cellulitis and other soft tissue infections. Wong et al. ${ }^{[13]}$ used a laboratory risk indicator for NF (LRINEC score) to detect NF even in clinically early cases. They used parameters such as the erythrocyte sedimentation rate, platelet count, and levels of C-reactive protein, glucose, hemoglobin, serum sodium, creatinine, potassium, chloride and urea for the diagnosis. The aim of this score was to distinguish NF from non-necrotizing soft tissue infections. Although computed tomography and ultrasonography are helpful in the differential diagnosis, a definitive diagnosis is made during surgical exploration. Skin anesthesia due to nerve damage and skin necrosis secondary to thrombosis of the subcutaneous vessels can occur in NF. ${ }^{[18]}$ Infection spreads rapidly, sometimes within hours, to the surrounding tissues and causes the disease to become more severe. In patients with suspected NF, marking the margins of the erythema and checking daily every 3 to 4 hours is helpful in making the diagnosis.

In a previous study, Kopp et. al. ${ }^{[12]}$ revealed a correlation between a high creatinine kinase level and amputation/mortality rate in electrical burn patients with muscle damage. In our study, we found a similar relationship between the creatinine kinase and lactate serum levels and the mortality/serious complication rate in NF. The serum creatinine level was greater than $2 \mathrm{mg} / \mathrm{dL}$ and the serum lactate level was greater than $6.8 \mathrm{mmol} / \mathrm{L}$ in the 2 patients who died. The serum creatinine and lactate levels in patients who underwent amputation/disarticulation were also significantly higher. Reduction in the serum creatinine and lactate levels after the appropriate debridement indicates a decrease in necrotic muscle, improvement in kidney function, and recovery from the inflammatory process. To our knowledge, there are no studies that have compared the serum lactate and serum creatinine levels of NF patients at the time of presentation and after debridement.

In our study, gangrene was observed in the ipsilateral upper extremity in 3 patients. The test results revealed that the organism cultured from the affected area was Staphylococcus aureus in these patients, and they were treated with amputation at the appropriate level. Gangrene of 4 extremities was seen in 2 patients; 1 case occurred in the postoperative period and 1 patient was gangrenous at the time of presentation. In the patient who developed this condition in the postoperative period, the etiology was an insect bite on the right foot at the malleol level. This patient also had a history of loss of vision due to an autoimmune episode. The rapid progression in this patient suggested that the autoimmune disease could have been a factor in the rapid progression of the disease. Following completion of below-knee amputation, gangrene symptoms were observed in all 3 other extremities. Both patients with gangrene in 4 limbs declined to have further limb amputation and died after long-term follow-up in the intensive care unit. There are no cases of NF related to gangrene of 4 extremities in the literature. Mortality is almost inevitable in these patients and perhaps they should be given a chance to spend time with their family and take a pause from treatment.

In NF, defect reconstruction and urgent surgical intervention is not preferred. Sufficient time should be allowed after debridement for the settlement of skin necrosis at the site of debridement and the surrounding tissue. In a previous study, reconstruction with skin grafts was reported in $48.4 \%$ and rotation flaps were used in $4.5 \%$ of NF patients, whereas in our study, the rate was lower, $27.6 \%$ and $19.5 \%$, respectively. ${ }^{[19-21]}$

It has been previously reported that the rate of amputation in NF was $23.5 \%$ and the rate of disarticulation was $1.4 \%{ }^{\text {[22- }}$ ${ }^{25]}$; in our study, the rate was $13.8 \%$ and $2.3 \%$, respectively. The NF mortality rate varies between $23 \%$ and $76 \%$, regardless of the treatment options, the according to previous reports. ${ }^{[26-28,3]}$ The mortality rate in our study was significantly lower than that of previous studies (9.2\%).

It was found that the shorter the time between the onset of symptoms and the time of presentation, there were fewer surgical debridements and a lower rate of mortality, amputation, and complications. Among the amputated patients, it was found that the symptoms were present for an average of 6.9 days. In both patients who died, the time between the onset of symptoms and the time of surgery was more than 5.5 days. NF is a surgical emergency that affects limbs and requires aggressive debridement of the affected tissues. Waiting and observing can lead to irreversible problems. If the patient is suspected of having NF, surgical debridement should be performed immediately.

There are some limitations of this investigation, which include a small sample size, the lack of a comparison group, lack of explanatory (correlation, regression) analysis, and lack of sensitivity analysis. However, despite our appreciation of the limitations of our investigation, we believe that the results of this study could be useful to the development of future prospective cohort studies and randomized controlled trials that focus on complications and mortality in patients with lower extremity NF. 


\section{Conclusion}

The results of our study suggest that the levels of serum lactate and creatinine can be used to predict mortality and morbidity in lower extremity NF patients.

\section{Disclosures}

\section{Ethics Committee Approval: N/A}

Peer-review: Externally peer-reviewed.

Conflict of Interest: We have no any conflict of interest.

Financial support: We have no any financial support.

Authorship contributions: Concept - F.I., S.K.; Design - F.l.; Supervision - F.I., S.K.; Fundings - F.I.; Materials - F.I; Data collection \&/or processing - F.I., S.K.; Analysis and/or interpretation - F.I; Literature search - F.l.; Writing - F.l.; Critical review - F.I, S.K.

\section{References}

1. Descamps V, Aitken J, Lee MG. Hippocrates on necrotising fasciitis. Lancet 1994;344:556. [CrossRef]

2. Kaul R, McGeer A, Low DE, Green K, Schwartz B. Population-based surveillance for group A streptococcal necrotizing fasciitis: Clinical features, prognostic indicators, and microbiologic analysis of seventy-seven cases. Ontario Group A Streptococcal Study. Am J Med 1997;103:18-24. [CrossRef]

3. Fontes RA Jr, Ogilvie CM, Miclau T. Necrotizing soft-tissue infections. J Am Acad Orthop Surg 2000;8:151-8. [CrossRef]

4. Patiño JF, Castro D. Necrotizing lesions of soft tissues: a review. World J Surg 1991;15:235-9. [CrossRef]

5. Green RJ, Dafoe DC, Raffin TA. Necrotizing fasciitis. Chest 1996;110:219-29. [CrossRef]

6. Lewis R. Necrotizing soft tissue infections. In: Meakins JL, ed. Surgical Infections in Critical Care Medicine. London: Churchill Livingstone; 1985. p. 153-71.

7. Baxter CR. Surgical management of soft tissue infections. Surg Clin North Am 1972;52:1483-99. [CrossRef]

8. Dellinger EP. Severe necrotizing soft-tissue infections. Multiple disease entities requiring a common approach. JAMA 1981;246:1717-21. [CrossRef]

9. Leitch HA, Palepu A, Fernandes CM. Necrotizing fasciitis secondary to group A streptococcus. Morbidity and mortality still high. Can Fam Physician 2000;46:1460-6.

10. Dellinger RP, Levy MM, Rhodes A, Annane D, Gerlach H, Opal SM, et al; Surviving Sepsis Campaign Guidelines Committee including the Pediatric Subgroup. Surviving sepsis campaign: international guidelines for management of severe sepsis and septic shock: 2012. Crit Care Med 2013;41:580-637. [CrossRef]

11. Trzeciak S, Dellinger RP, Chansky ME, Arnold RC, Schorr C, Milcarek $B$, et al. Serum lactate as a predictor of mortality in patients with infection. Intensive Care Med 2007;33:970-7. [CrossRef]

12. Kopp J, Loos B, Spilker G, Horch RE. Correlation between serum creatinine kinase levels and extent of muscle damage in electrical burns. Burns 2004;30:680-3. [CrossRef]

13. Wong CH, Khin LW, Heng KS, Tan KC, Low CO. The LRINEC (Laboratory Risk Indicator for Necrotizing Fasciitis) score: a tool for distinguishing necrotizing fasciitis from other soft tissue infections. Crit Care Med 2004;32:1535-41. [CrossRef]

14. Murphy G, Markeson D, Choa R, Armstrong A. Raised serum lactate: a marker of necrotizing fasciitis? J Plast Reconstr Aesthet Surg 2013;66:1712-6. [CrossRef]

15. Wall DB, de Virgilio C, Black S, Klein SR. Objective criteria may assist in distinguishing necrotizing fasciitis from nonnecrotizing soft tissue infection. Am J Surg 2000;179:17-21. [CrossRef]

16. McHenry CR, Piotrowski JJ, Petrinic D, Malangoni MA. Determinants of mortality for necrotizing soft-tissue infections. Ann Surg 1995;221:558-63. [CrossRef]

17. Rea WJ, Wyrick WJ Jr. Necrotizing fasciitis. Ann Surg 1970;172:95764. [CrossRef]

18. Chelsom J, Halstensen A, Haga T, Høiby EA. Necrotising fasciitis due to group A streptococci in western Norway: incidence and clinical features. Lancet 1994;344:1111-5. [CrossRef]

19. Gonzalez MH, Kay T, Weinzweig N, Brown A, Pulvirenti J. Necrotizing fasciitis of the upper extremity. J Hand Surg Am 1996;21:689-92.

20. Tsai YH, Hsu RW, Huang TJ, Hsu WH, Huang KC, Li YY, et al. Necrotizing soft-tissue infections and sepsis caused by Vibrio vulnificus compared with those caused by Aeromonas species. J Bone Joint Surg Am 2007;89:631-6. [CrossRef]

21. Wang $\mathrm{KC}$, Shih $\mathrm{CH}$. Necrotizing fasciitis of the extremities. J Trauma 1992;32:179-82. [CrossRef]

22. Angoules AG, Kontakis G, Drakoulakis E, Vrentzos G, Granick MS, Giannoudis PV. Necrotising fasciitis of upper and lower limb: a systematic review. Injury 2007;38 Suppl 5:S19-26. [CrossRef]

23. Ryssel H, Germann G, Kloeters O, Radu CA, Reichenberger M, Gazyakan E. Necrotizing fasciitis of the extremities: 34 cases at a single centre over the past 5 years. Arch Orthop Trauma Surg 2010;130:1515-22. [CrossRef]

24. Khanna AK, Tiwary SK, Kumar P, Khanna R, Khanna A. A case series describing 118 patients with lower limb necrotizing fasciitis. Int J Low Extrem Wounds 2009;8:112-6. [CrossRef]

25. Rieger UM, Gugger CY, Farhadi J, Heider I, Andresen R, Pierer G, et al. Prognostic factors in necrotizing fasciitis and myositis: analysis of 16 consecutive cases at a single institution in Switzerland. Ann Plast Surg 2007;58:523-30. [CrossRef]

26. Wong $\mathrm{CH}$, Chang HC, Pasupathy S, Khin LW, Tan JL, Low CO. Necrotizing fasciitis: clinical presentation, microbiology, and determinants of mortality. J Bone Joint Surg Am 2003;85-A:1454-60.

27. Golger A, Ching S, Goldsmith CH, Pennie RA, Bain JR. Mortality in patients with necrotizing fasciitis. Plast Reconstr Surg 2007;119:1803-7. [CrossRef]

28. Tiu A, Martin R, Vanniasingham P, MacCormick AD, Hill AG. Necrotizing fasciitis: analysis of 48 cases in South Auckland, New Zealand. ANZ J Surg 2005;75:32-4. [CrossRef] 